\title{
Research on the Dilemma and Development Trend of International Trade Governance
}

\author{
Zhaoan $\mathrm{Han}^{1}$, Haizhen $\mathrm{Wu}^{2,} *$ \\ ${ }^{1}$ School of Economics \& Management, Northwest University, Xi’an, Shaanxi, China \\ ${ }^{2}$ School of Management, Xi'an University of Architecture and Technology, Xi’an, Shaanxi China
}

Keywords: International trade governance; The mire; The development trend

\begin{abstract}
At present, the changeable trade system, regional trade agreement, non-institutional arrangement and unilateralism jointly constitute the general pattern of international trade governance. Different governance mechanisms show their own characteristics, but they have certain similar functions due to their own attributes that jointly play a role in the development of international trade. Firstly, this paper analyzes the dilemma of the current international trade governance, and concretely summarizes the five practical dilemmas. This paper analyzes the future development trend of international trade governance from six aspects: development achievements of international trade, diversification of international trade, high efficiency of decision-making mechanism, diversification of settlement system, international export of infrastructure products and inclusive development of international trade.
\end{abstract}

After the Second World War, western developed countries led by the United States led the construction of the general agreement on tariffs and trade (GATT), which later evolved into the present world trade organization (WTO). The improvement of the multilateral trading system greatly promoted the development of global trade liberalization and promoted the rapid growth of international trade scale. With the deepening of economic globalization, the rise of emerging economies strength, economic strength of the United States and other developed countries relative decline, the developed countries of the wave of globalization and nationalism, the multilateral trade body constitution in such aspects as impartiality, negotiation mechanism, decision-making mechanism becomes increasingly defects, multilateral trade constitution in modern trade show in the treatment of the low efficiency or even no efficiency, restricted the further development of international trade. The multilateral trading system cannot solve all the problems in the global economy, the regional economic cooperation can make up for the multilateral trading system to some extent in many difficult to obtain the coordination between member states, regional trade agreements have interest convergence between member countries, the advantages of the decision-making mechanism in colleges and universities, from a certain extent, maintaining the steady rise in international trade. In 2016, the UK's vote to leave the EU, trump's victory in the US election and other black swan events have led to a trend of bilateral and unilateralism in international trade. The development of international trade will face greater uncertainty and the effectiveness of the international trade governance mechanism will face greater challenges.

\section{The Realistic Dilemma of International Trade Governance}

\subsection{The shake of WTO trade governance mechanism}

The WTO trade governance system is shaken mainly in three aspects. Firstly, the internal system defects of WTO become more and more obvious: the WTO decision-making inefficiency has become a platitude, because the existing decision-making mechanism consensus principle restricts the freedom and flexibility of negotiations, increases the possibility of negotiation deadlock, and easily turns into a veto system; Developing countries demand that developed countries enhance market access in primary industries such as agriculture, while developed countries demand that developing countries set high standards in services and the environment. The defects of the 
procedure transparency and the insufficient participation of the third party in the WTO dispute settlement mechanism are exploited by the United States and other developed countries, resulting in the failure of the dispute settlement mechanism to operate normally. Secondly, some western countries began to promote "protectionism" and "isolationism", raise tariff barriers, restrict technology transfer, and attempt to create a closed clique by abandoning the WTO trading system. In essence, this is an act of unwillingness to bear the responsibility of global trade governance. Finally, the nationalism under the influence of populism in western countries transfers the increasingly fierce class contradictions in China to the whole world, and the problem of social equity in western countries cannot be effectively solved, which leads to the emergence of populism under the influence of nationalism. Therefore, "protectionism" and "isolationism" are taken as the solutions to control social division.

\subsection{American hegemony hinders effective governance of global trade}

The United States relies on the dominant position of the dollar in trade settlement and the dominant position in the multilateral trading system to realize its hegemony, which is mainly manifested in the unilateralism of the United States. First of all, the bretton woods system into dollars into core lay a solid foundation for the international monetary system, as the dollar in global trade settlement and cross-border investment field use frequency more and more high, the dollar quickly replace gold as the world's major international reserve assets, thus formed the dollar hegemony in the global monetary system; Second, the United States through rules and issues leading to achieve control of the multilateral trade system, the United States in the process of building the multilateral trading system, to its domestic law in the legislative spirit and some specific regulations imposed to the multilateral trading system, negotiating agenda constructed in successive multilateral trade negotiations, to the United States focused on issues including environmental protection, labor standards, trade in services and intellectual property rights is introduced into the multilateral trading system, in order to control the trend of the multilateral trading system. Finally, the hegemony of the United States in global trade governance is not only manifested in the dominance of international economic and trade rules, but also in the unilateralism of multilateral trade rules. In dealing with global trade issues, the United States only ACTS in its own judgment and national interests, regardless of the needs and opinions of the international community [1].

\subsection{Changes in the international economic and political environment pose new challenges to trade governance}

The collective rise of emerging economies and developing countries leads to the shift of global power, which brings about the change of global trade governance structure. On the one hand, the unfair international economic and trade rules have resulted in the structural imbalance of global income distribution, which has gradually lost the effectiveness and legitimacy of trade governance during the rise of emerging economies. On the other hand, contrary to the tilt of global economic power to emerging economies, the distribution of voting rights and right of speech in global trade governance does not fully reflect the revolutionary changes in the international economic power pattern. The intensification of the differences in the governance objectives of participants makes the need for emerging economies to have a say in global trade governance more urgent. Finally, the power structure of global trade governance follows the dual logic of evolution and competitiveness [2]. In other words, in addition to institutional renewal, the global trade governance structure is bound to need to make adaptive adjustments to the changed international power structure. However, European and American countries try not to recognize or accept the rise of emerging countries and participate in global trade governance, and continue to eliminate and marginalize the importance of emerging countries and their civilization development in global trade governance.

\subsection{The global trade governance mechanism lacks legitimacy and representation}

The lack of legitimacy is mainly reflected in two aspects. First of all, the current global trade center - edge structure under curing governance system, part of the least developed countries and 
even be excluded from the depth of economic globalization, lost the basic development opportunities, the north-south economic gap widening, and from the perspective of the development assistance of most countries, the global development aid did not get the desired effect, global trade governance ineffective contributed to the global distribution of unfair, undermines the legitimacy of the current global trade management system. Second, global trade governance mechanism of neutral performance, which can be realized using rule implementation advantage in developed countries, increased the risk of global trade governance and differences, global trade governance mechanism of fragmentation characteristics embodied in the lack of real global trade governance system principle and the idea of consensus, and that is exactly what trade governance mechanism is the root of the lack of legitimacy, law can constraint the behavior of a country and can become members abide by the principles and the concept of consensus. On the one hand, the rule dilemma under the existing multi-level governance model is manifested as the increasing constraints of multilateral governance and regional governance. On the other hand, the fragmentation of global economic governance mechanisms, resulting in a lack of representativeness and effectiveness, has fragmented the integrity of the global trading system.

\subsection{Global trade governance lacks a systematic assessment system}

The difficulty of global trade governance assessment is the complexity and frequency of trade governance itself, and the inconsistency of governance subjects' demands for trade governance, as well as the variability of assessment indicators and weight distribution. The complexity of global trade issues determines their long-term existence and difficulty to be solved. Specifically, the relations and interest demands between developed countries, developing countries, north and south countries, multinational enterprises and governments, and non-governmental organizations and governments are interlaced. Frequent global trade issues put global trade governance into a passive position. Global trade is characterized by the same problem repeat and new problems emerge, to repeat the same problem that trade governance has not fundamentally eliminate the root cause, new trade issues frequently exposed the vulnerability of trade management, global trade complexity and frequent interaction of global trade governance are in trouble, more increased the difficulty of the trade management assessment. There is a serious imbalance in the development of the global economy. Different economies have different interest demands for international trade, and international trade governance patterns are diversified. The existing evaluation system of international trade governance mainly focuses on specific countries, which is far from reaching the global level of international trade governance. The global trade governance assessment system should have both macro guidance and micro operability. The assessment system mainly includes assessment subjects, objects, tools and indicators. First of all, it is very important to choose the right evaluation subject, which contains the problem of circular supervision. Secondly, the evaluation object should make a scientific choice between the governance behavior and the operation of the governance mechanism. Third, different trade governance models need to match different assessment methods and tools; finally, the selection of evaluation indicators is more complex, such as the issue of qualitative indicators versus quantitative indicators [3].

\section{The Development Trend of International Trade Governance}

Contemporary international trade governance mechanism for the multilateral trading system, regional trade agreements, the institutional arrangement, the coexistence of pluralistic phenomenon such as unilateralism, world trade present trade policy formulation and implementation of power "decentralization" and "fragmentation" trend, no doubt increased the difficulty of the global trade governance, however, free trade can increase the basic facts of the human welfare will not change, should adhere to the basic idea of free trade, trade governance system of economy, culture and national differences in the face, actively explore conforms to the common interests of all the peoples of the world trade development path.

We will continue to take the development of international trade as the central task. Since Adam Smith, many economists have demonstrated the positive benefits of free trade to social welfare. 
International trade governance and measurement should set up the banner of free trade and carry out the maximum degree of opening to the outside world with respect to the political, economic, cultural, institutional and religious differences among countries. It is necessary to recognize the differences in development levels and needs among countries, especially the antagonism between developed countries and developing countries in terms of development goals, as well as the exploitative nature of developed countries and their efforts to restrain the development of developing countries through international trade through the existing international trade governance system.

Pay attention to the richness of international trade level, the diversity of the main body. At present, the mainstream way international trade for developing countries to developed countries export labor and resource intensive products, so in exchange for limited capital and technology intensive products, disguised essence for developed countries to developing countries for exploitation, the existing developed countries dominate the establish of multilateral trade physical inequality can't break the disequilibrium situation. In the face of the blockade by developed countries, developing countries should wake up to the world situation, tap the potential and level of international trade, and actively build a flexible international trading system. The international trade governance system should adhere to the principle of fairness and openness to the level of global interests. It should not represent any interest subject, still less be subject to any hegemonism. In the future, international trade cooperation will be closer and more diversified, which is a concrete manifestation of the efficient operation of the international trade governance system.

Under the principle of a community of Shared future, the camera decision-making mechanism will be promoted. One of the reasons why regional trade agreements are more efficient than volatile trading systems is the efficiency of decision-making mechanisms. The world trade organization (WTO) will "package deal" principle as a decision-making mechanism, it reduces the degrees of freedom and flexibility of the negotiation between countries greatly reduces the efficiency of negotiations, and developed countries led to establish the principle of inhibition of developing countries is becoming a developed countries economic transformation, industrial upgrading, and progressive "legal" means. The decision-making mechanism of the existing multilateral trading system cannot meet the development demands of many developing countries, and it is a major institutional barrier to the transformation of international trade pattern to strictly limit the international trade pattern to the situation dominated by developed countries, and it is even less able to meet the demands of the increasingly complex development trend of international trade cooperation. Improving the efficiency of decision-making is an important task for improving the international trade governance mechanism. First, member states should strictly adhere to the basic principle of community of Shared future, pursue their own international trade interests under the fair competition mechanism, and resolutely avoid ACTS that harm the interests of third parties. Secondly, a free and flexible bilateral and multilateral decision-making mechanism should be established, and decision-making can only be effective through the review of international supervision organizations.

We will actively promote a diversified international trade payment system. After the Second World War, the US dollar established the core position of international trade payment. With the disintegration of the bretton woods system, the US dollar was issued without anchor, and the link between the US dollar and oil strengthened the hegemony of the US dollar in the world payment system. International trade with the single dollar settlement way has great uncertainty and risk, the circulation of the dollar is decided by the federal reserve, and the fed represent the fundamental interests of the American people, every time the fed to adjust the interest will affect the nerve of the international trade affairs, bring greater uncertainty for the international trade development; As the core of international trade settlement system, the issue of us dollar is subject to the most hegemonic international institution in the world, which undoubtedly increases the risk of international trade settlement. Promoting the diversification of international trade payment system can effectively improve the transaction efficiency, reduce the uncertainty of international trade settlement, and provide a high-quality settlement environment for the development of international trade, which is 
an important manifestation of improving the efficiency of international trade governance.

Strengthening the international export of public goods and facilities. The construction of public goods and facilities in a country can provide basic support and convenience for the development of its economy and trade, and is conducive to the sustainable development of its economy. Developed countries dominated trade pattern rarely involved in the field of infrastructure construction investment, this is the development and restrict developing countries to achieve sustained exploitation, the nature of the ultimate goal of globalization is to realize the common prosperity of all countries, share in global economic development, the output is represented by the infrastructure of public products improve poor countries get sense of economic development, is to help poor countries develop domestic economy, effective path actively into the international division of labor system, is an effective measure to solve the civil development imbalance disease.

We will actively advocate the harmonious and inclusive development of international trade. Stand still adhere to the concept of the global community of fate, the destiny of thoughts rooted in countries around the world, the reform in the us and Europe countries such as the dominant global trade governance mechanism based on the interests of the developed countries, together with global development as a starting point, through the construction of common global development path, the share of the global development as the final result, on mutual respect, seeking common ground while putting aside differences under the big background, the principle of tolerance to advocate for the harmony of international trade development. Global harmonious and inclusive development is the ultimate goal of international trade governance, which aims to reduce the imbalance of economic development among countries and ultimately achieve common prosperity.

From the current situation of international trade pattern and international trade governance, developed countries are still the dominant players in international trade pattern and governance, and it is difficult for developing countries to break through the basic pattern of exploitation by developed countries under the existing multilateral trading system. Regional trade agreements, the institutional arrangement, the rise of unilateralism, but also increased the difficulty and complexity of the governance of international trade, so the governance of international trade both from the perspective of international trade development goals, methods such as macro measure, decision-making mechanism, international trade settlement system should also be considered, such as product type micro level, in front of the governance mechanism to form unified international trade, international trade governance will be a difficult system engineering.

\section{References}

[1] Liu Zhizhong. Restructuring of global trade governance system under the background of "One Belt and One Road” [J]. Northeast Asia forum, 2008, 27(05): 70-82+128.

[2] Cheng Dawei. Changes in the global trading system under the administration of the United States and China's trade governance countermeasures [J]. Political economy review, 2008, 9(04): 97-109.

[3] Zhong Ying. Analysis of global trade governance model -- from the perspective of regional trade agreement [J]. International economic and trade exploration, 2015, 31(08): 77-89. 